\title{
Rethinking Working-class Politics: Organising Informal Workers in Argentina
}

\author{
Maisa Bascuas, University of Buenos Aires, Argentina \\ Ruth Felder, Ontario Tech University, Canada \\ Ana Logiudice, University of Buenos Aires, Argentina \\ Viviana Patroni, York University, Canada
}

\begin{abstract}
Our article engages with discussions about the implications of precarious work and its impact on workers' capacity to organise by analysing the case of Argentina's Confederation of Popular Economy Workers (CTEP, Confederación de Trabajadores de la Economía Popular). The organisation was created in 2011 with the aim of representing a broad and heterogeneous group of workers in varying conditions of informality, precarious self-employment and workfare programmes. We trace the history of the organisation and analyse its development by focusing on the role of social assistance as a crucial expression of the changing relations between precarious workers and the state. Social assistance has provided some resources for addressing the reproduction needs of precarious workers and of the territories in which they live, and also the material means through which an organisation like CTEP has sought to consolidate its political work among precarious workers. Nonetheless, social assistance has also worked as a means to circumscribe broader demands for change into issues to be addressed through social policy. Our argument is that central to CTEP's trajectory as an organisation of precarious workers was its attempt to break away from the narrow confines of social assistance, pushing for changes that would allow its members to gain some autonomy both materially and institutionally.
\end{abstract}

\section{KEYWORDS}

Argentina; precarious worker organisations; CTEP; social assistance policy

\section{Introduction}

Precarious labour and the consequences of precarity have become buzzwords in contemporary debates about life under capitalism. Because of this, questions about the implications of various forms of precarity for worker organising have acquired renewed relevance as the power of the working class continues to be challenged by what now seems like capitalism's endless array of resources to accumulate at the expense of wages and social wellbeing. ${ }^{1}$ Our article engages with

\footnotetext{
${ }^{1}$ We use the notion of precarious labour to refer to the broad range of working realities that includes several forms of non-standard employment, namely workers who are not registered and work for a registered or unregistered employer, contract workers who are misclassified as independent contractors, self-employed workers, and waged and unwaged family workers. We use precarity rather than informality which is often used in the literature to refer to various forms of non-standard work because we want to emphasise the
}

Global Labour Journal, 2021, 12(3), Page 244 
discussions about labour precarity and precarious labour organising by analysing the case of Argentina's Confederation of Popular Economy Workers (CTEP, Confederación de Trabajadores de la Economía Popular), which was created in 2011 with the aim of representing a broad and heterogeneous group of workers in varying conditions of precarity, precarious self-employment and workfare programmes.

As an overall approach to our enquiry, we aim to bring together two sets of discussions that for the most part have been developed separately. The first is the reality of various forms of precarious work and the challenges it represents for workers, their identities and their forms of collective action. The second is the relationship between precarious workers and the state and its social assistance policies.

Beginning with the experience of organisations of the unemployed in the 1990s, works in the first group have contributed to a better understanding of the ways in which precarious and unemployed workers managed to forge new identities even when confronting an experience that has traditionally been associated with isolation and social fragmentation (Svampa and Pereyra, 2003; Masetti, 2004; Dinerstein, 2014). Some studies have connected such a capacity with longerterm traditions of working-class organising and collective identities (Lucita, 2001; Benclowicz, 2015). In studies about CTEP, these preoccupations have advanced a new focus on the capacity of precarious workers to re-articulate the notion of work and working-class organising (Abal Medina, 2016; Bruno, Coelho and Palumbo, 2017), while questioning the strict separation between formality and informality (Fernández Álvarez, 2019, 2020) as well as the spheres of production and reproduction (Pacifico, 2017; Fernández Álvarez and Perelman, 2020).

Within the second body of work, a key theme has been the political implications of demands for social assistance, both for relations between organisations and the state and for the organisations themselves (Svampa, 2008). In some cases, these relationships have been addressed as disempowering (Álvarez Leguizamón, 2006; Murillo, 2008) while others have seen them as spaces of contention through which social movements representing the unemployed have sought to establish their own bases of power (Garay, 2007; Rossi, 2017). While all these contributions inform our understanding of the multiple processes at play in the political strategy of CTEP, we suggest it is in bringing together its experience both as an organisation mobilising around labour rights and engaging in relations of conflict and cooperation with the state around social assistance that we truly gain an appreciation of the complexities of organising precarious workers.

With this objective in mind, our paper focuses on CTEP's drive to gain the recognition of its members as workers and the strategies it followed since its origins with that aim: first, the recognition of the social value of the work of its members and the institution of a social salary; and second, CTEP's demand to be formally recognised as a union both by the state and by other unions. In our study we pay particular attention to social assistance policy as a crucial expression of the changing relations between precarious workers' organisations and the state. Social assistance has provided crucial channels through which the state has not only addressed the demands of precarious workers but also circumscribed them as issues of social policy. However, assistance has also been a resource for addressing the reproduction needs of precarious workers and of the territories in which they live and, at the same time, a vehicle for building the foundations for the political action of these workers. CTEP has also fought for its members to be recognised as workers with the right to unionise and, as a union, to become part of the General Labour Confederation

involuntary nature of these forms of work, the vulnerability workers are exposed to, and the implications for their lives. 
(CGT, Confederación General del Trabajo), and to gain the right to engage in collective bargaining and wage negotiations similar to that of other groups of workers. These themes guide our discussion. Our argument is that central to CTEP's trajectory as an organisation of precarious workers was its attempt to break away from the narrow confines of social assistance, pushing for changes that would allow its members to gain some material and institutional autonomy. The struggles for a social salary and its legal recognition as a union are both cases in point.

We first present a theoretical reflection on some of the key concepts in our discussion - first, the rise of precarious labour and the challenges it has posed for labour organising; second, the crisis of social reproduction and the ways in which workers have sought to address it; and third, the opportunities and challenges social assistance has created for these workers and their forms of organising. The next section provides a characterisation of CTEP and the historical background from which it emerged. This discussion provides the context for examining the renewed organising efforts of precarious workers with the creation of CTEP. The following section focuses on the period of political change and economic crisis that followed the election of a right-wing government (2015-2019). Finally, we offer some concluding reflections on the implications of precarious workers' struggles.

The article is based on our fieldwork findings and the knowledge gained through activism. Fieldwork includes twenty unstructured interviews with local leaders and rank-and-file members of unemployed workers' movements, members of CTEP and of existing national labour confederations, labour lawyers working to support informal workers' cooperatives and state officials from the Labour and Social Development ministries conducted between 2016 and 2020. Interviewees were identified through personal contacts and snowball techniques. We also rely on official statistics and documents produced by the state and CTEP. Finally, we draw upon critical reflections on the knowledge gained through direct engagement with some of the movements and organisations analysed in the paper. This article is thus the product of a dialogue between the authors about our perspectives on labour studies, assistance policies and the political dynamics of popular economy workers. This exchange has enriched our understandings of labour, labour organising and the relation between organised workers and the state, providing us with new ways of looking into the realities in labour organising under increasingly heterogeneous conditions.

\section{Precarious Work, Social Reproduction and Working-class Struggles in the Twenty-first Century}

Beyond the usual gamut of challenges related to organising workers, there are additional constraints to collective action by precarious workers, who are often wageless. As discussed in the Introduction to this Special Issue, there is a large body of literature in Latin America and elsewhere in the Global South on precarious workers and their particular vulnerabilities vis-à-vis economic and political transformations. In the context of the crisis of standard work - that is, continuous employment with benefits - in both the Global North and South, and the proliferation of various forms of precarious work that have accompanied the restructuring of capitalism since the 1970s, questions about the likelihood of precarious workers' collective action have gained traction. Discussions have been ignited by Standing's (2011) influential definition of the precariat as a "class in the making", whose members tend to be alienated from contemporary politics. These workers constitute a decidedly heterogeneous group, most of the time without links to a shared or identifiable workplace and employer, often experiencing forms of precarity and economic and extra-economic challenges in substantially different ways. Lacking wages and a connection to a site of production, precarious

Global Labour Journal, 2021, 12(3), Page 246 
workers' struggles are framed in ways that depart substantially from the practices of conventional labour unions. These characteristics provide some explanation for both the obstacles traditional unions have encountered in organising informal workers and, equally important, the fact that these workers have often sought alternatives to conventional working-class forms of organising as channels for their collective action (Bonner and Spooner, 2011; Agarwala, 2014). Nonetheless, there are a number of successful organising experiences among informal workers that show that, while difficult, workers do find the ways to express their demands collectively, as has been the case with domestic workers, street vendors, home-based workers, recyclers and so on (Bonner and Spooner, 2011; Chen, 2012; Argawala, 2014; Rosaldo, 2016). Moreover, emerging informal workers' organisations have managed to provide options to sectors that have remained historically marginal to union's spheres of action (Argarwala, 2014).

In the absence of common workplaces, key to making organising possible has been the creation of a shared social space for resistance that facilitates the encounter with other workers and bridges differences (Felder and Patroni, 2018a: 4). CTEP has found a means to address some of the most serious challenges it faces to find the terms of unity in the concept of popular economy (Fernández Álvarez, 2020). As Forni, Nougués and Zapico (2020) suggest, the popular economy is a device that made it possible for various movements and organisations to foster the emergence of a common identity. Yet, the popular economy has also been key for CTEP to demarcate a complex universe of production and reproduction activities carried out by workers who must make a living outside of the formal economy; as such, it is the most vivid manifestation of the fact that under the current distribution of power between capital and labour, the economy is no longer able to create jobs for all workers. CTEP's leaders have called attention to the fact that the exclusion of precarious workers from wage relations often entails their exclusion from the rights and protections other workers enjoy (Pérsico and Grabois, 2014), even when these workers usually perform activities that are critical for the capitalist economy, while the value of their work is indirectly appropriated by capital (Grabois, 2014). ${ }^{2}$

As the possibilities of earning a wage become grimmer, an increasing number of workers need to find alternative ways to secure their reproduction. One characteristic in the organisation of CTEP is exactly the relevance of struggles around issues pertaining to social reproduction. Indeed, its organising is in many ways a response to the crisis in social reproduction created by the structural growth of unemployment and precarity. Like the notion of social reproduction itself, these struggles around social reproduction are "inevitably crisscrossed by contradiction, within which lies room for resistance and rupture and for the creation of alternative forms of social reproduction" (Dinerstein and Pitts, 2018: 483). Yet, as Katz (2001: 718) puts it, "[s]ocial reproduction is precisely not 'revolutionary', and yet so much rests on its accomplishment, including - perhaps paradoxically - oppositional politics".

As several authors have shown, self-organising is fundamental for the social reproduction of

\footnotetext{
${ }^{2}$ With this, CTEP distanced itself from more conventional views of the social economy which have been used to characterise activities that exist beyond formal markets. The social economy is understood as a space in which economic activities are guided by the principle of solidarity, and in which cooperation prevails over competition (Coraggio, 2020). It also suggests a choice on the part of workers. In other words, the popular economy entails relations of exploitation that often transcend formal wage relations, and brings together groups of workers affected by different forms of precarity. Equally important, the popular economy is a way to emphasise the centrality of work in organising the life of those who have been excluded from formal wage relations (Hindi, 2020).
} 
precarious workers (Lazar and Sánchez, 2019; Fernández Álvarez, 2020). But usually, reproduction also entails some forms of interaction with the state and access to state funding, and this has posed a political dilemma for CTEP. While reliance on the state might be inescapable, it creates two fundamental problems. One is its contingency. The state might or might not have the resources required to provide social assistance, a supplementary wage or a universal income. Social movements might have very little leverage in ensuring the availability of these resources, and this creates political vulnerabilities the state can manipulate in its favour. The other problem relates to the political risks that the subordination to state assistance generates as it brings to the surface assumptions about the poor under capitalism, in particular their being unproductive and superfluous to society. In struggles around reproduction by popular economy workers, we thus see an attempt to vindicate the worth of these workers' contributions to society in terms of the value of their productive and reproductive activities and, therefore, their rightful claim to a share of the wealth generated. Indeed, as we argue, the political resignification of social assistance has been at the core of CTEP's strategy.

Generally speaking, social assistance has often been connected to poverty relief programmes and other planned public interventions within areas of social development (Lo Vuolo et al., 1999). It entails "mechanisms to transfer good and services to those individuals and groups not absorbed into the expanding labour market or absorbed in ways so irregular and tenuous as to be insufficient to ensure the satisfaction of basic living conditions in monetised societies" (Soldano and Andrenacci, 2006: 15). It is usually guided by notions about the satisfaction of needs rather than the recognition of rights (Danani and Hintze, 2020). The emphasis on needs has led to assistance being associated with the discretionary power of the state to both define recipients and exercise political control over them. The most radical version of this line of thinking draws a direct connection between social assistance and political clientelism (Sojo, 2007). In our work, however, we understand social assistance as the body of policies connected to secondary income redistribution aimed at those not protected through the provisions established under formal employment relations.

In Argentina, social assistance expanded considerably during the 1990s in response to profound transformations in labour markets and the parallel undermining of the body of protections that had existed to regulate wage work. During those years, social policy was characterised by its rather limited impact and reach, in terms of both the size and characteristics of the target populations and the goods and services provided through the programmes. Assistance was also conditional on some kind of work by the recipients. To organise this work, social assistance programmes relied on government institutions - fundamentally, local governments and, to some extent, organisations of unemployed workers (Grassi, 1997, 2003; Vilas, 1997; Andrenacci, 2002). More recently, some programmes replaced work requirements by a new type of conditionality that emphasises recipients' compliance with health controls (vaccinations, checkups, etc.) and schooling for dependent children - a change that individualises recipients' connection to the programme and also tends to place considerable pressure on women (Pautassi, Arciadiácono and Straschnoy, 2013). There has been a broad consensus that social assistance in general and conditionality in particular have been a main instrument in the hands of the state to address social conflict (Álvarez Leguizamón, 2006; Murillo, 2008), and have been intended to discipline recipients of assistance (Brown, 2017). In our view, social assistance programmes and their conditionalities have also provided resources and opportunities critical for both the existence of collective initiatives that ensure social reproduction as well as for sustaining mobilisation and organising (Natalucci, 2012; Longa, 2019). This has been most clearly evident when social assistance has 
supported and promoted the creation of cooperatives and other forms of collective initiatives in which social organisations played a central role. As we are going to show below, this role has often exceeded the one formally assigned by the state. Even though the state has been central in influencing precarious workers' forms of organisation through the allocation of resources and the definition of policy orientations, precarious workers' organisations have sought to advance their own political agendas that have involved cooperation and conflict with the state and have evolved in line with changing political junctures. Gradually, several of these organisations converged in CTEP and in the demand for recognition of their members as workers, rather than assisted poor or unemployed.

The creation of CTEP, its connection to previous organising experiences, and the consolidation of its way of understanding the way forward for precarious workers is the subject of the next section.

\section{The Politicisation of Precarious Labour in Argentina: The Innovations of CTEP}

Our most important experience as organisations [at the time of the creation of CTEP] could be traced back to the 1990s - for some of us our roots went even deeper, into the 1980s and, of course, even the 1970s (Secretary General of CTEP Esteban Castro, cited by Muñoz, 2019).

As we discussed above, the popular economy plays a central role in CTEP's strategy of political organising. It is the space of production and reproduction, and so it has been a key demand of the organisation to gain the legal and material means required to ensure that those jobs provide viable livelihoods for these workers. The founding of CTEP in 2011 was aimed at bringing political representation to these popular economy workers.

They are street vendors, they recycle garbage, they contribute to community services like neighbourhood kitchens and caring for children and the elderly, they produce food in small plots of land, and they often find sporadic waged work as informal labourers. Some have undertaken these survival activities individually, and many others do so as members of cooperatives that have either been autonomously constituted, as is the case with worker-controlled enterprises, or formed through the mediation of the state. The range of their work experiences reflects the diversity of trajectories leading workers into the popular economy, a concept that, as we suggest above, has become instrumental in capturing the potential of unity among this population.

The heterogeneity in the work trajectories of the CTEP rank and file is mirrored by the substantial diversity in the political forces that brought the organisation together. Some of these movements had been quite close to the Fernández de Kirchner government, as was the case with Evita Movement (Movimiento Evita) and its leader Emilio Pérsico and the National Indigenous Peasant Movement (MNCI, Movimiento Nacional Campesino Indígena). Others have tight connections with the social work of the Catholic Church, as is the case with the Movement of Excluded Workers (MTE, Movimiento Nacional de Trabajadores Excluidos). And yet others trace their origins to different radical left traditions or are independent, most notably the Popular Movement for Dignity (MPLD, Movimiento Popular La Dignidad), the Land Workers Union (UTT, Unión de Trabajadores de la Tierra), The Powerful (La Poderosa) and a number of local organisations. Many of these groups share roots in the organisations of unemployed workers of the late 1990s and early 2000s, which gradually reformulated their demands and their own nature. While we cannot delve in detail into the history and internal politics of the precarious workers'

Global Labour Journal, 2021, 12(3), Page 249 
movement in Argentina, in what follows we address a few notes with the expectation it will contribute to a better understanding of CTEP's goals and actions, and also its strategy vis-à-vis the state.

\section{Workers' organisations and social assistance policy in times of crisis and recovery}

The 1990s was a decade of profound economic change for Argentina, with the most negative effects felt by the workers in the country. It was also a moment of significant transformations in labour organising, when established unions faced the twin challenges of rising unemployment and crumbling labour rights, as neo-liberal reforms and austerity became entrenched in the country. By 2002, unemployment reached 21.5 per cent and involuntary underemployment 24.3 per cent. In 2003, almost 44 per cent of workers were unregistered (Felder and Patroni, 2018b).

It was in this climate of mounting losses for workers that new forms of collective action emerged, particularly among those segments of the working class most affected by unemployment, underemployment and impoverishment. The collapse of neo-liberalism in the country and the nature of the period that succeeded it cannot be understood without considering the role of these workers. Perhaps the most emblematic struggle of the time was that of the unemployed workers, who came to be known as piqueteros for their use of road blocks (piquetes) as a form of protest (Cross and Monte Cató, 2002; Svampa and Pereyra, 2003; Felder and Patroni, 2011). Starting in the mid1990s, their demands for state assistance and jobs transformed the political dynamics of the labour movement in Argentina.

Some unions came to see the growing numbers of unemployed and precariously employed as a central focus in the struggles against neo-liberalism. In 1992, major unions within the public sector split from the mainstream CGT to create the Argentine Workers' Central (CTA, Central de Trabajadores de la Argentina), which attracted organisations of the unemployed and other territorial organisations representing a wide range of informal and precarious workers. Other unions within the service and transportation sectors, while remaining within CGT, defied its leadership in 1994 by creating the Movement of Argentinean Workers (MTA, Movimiento de Trabajadores Argentinos). In the second half of the 1990s, the confluence of organisations of the unemployed within MTA and CTA, as well as other organisations in the piquetero movement, created a powerful opposition movement. The importance of these alliances in cementing the power of various organisations of the unemployed cannot be overstated (Patroni, 2018).

The government responded to this upsurge of social mobilisation with a combination of repression and some novel forms of state intervention - namely, workfare and anti-poverty programmes that targeted poor unemployed workers. From this time on, the state's forms of engagement with social organisations in allocating workfare stipends became a key area of contention (Svampa and Pereyra, 2003). In particular, the deployment of social programmes became a new stage for the complex interaction between the state and the organisations of unemployed workers and their patterns of confrontation and incorporation (Freytes Frey and Cross, 2005; Garay, 2007). ${ }^{3}$ Thus while it is true that governments might have used work programmes as a means to consolidate their patronage networks (Levitsky, 2003), it is also the case that organisations of the unemployed were able to use these programmes to strengthen their own positions vis-à-vis the communities they hoped to represent (Freytes Frey and Cross, 2005;

\footnotetext{
${ }^{3}$ The involvement of social organisations in the management of social assistance programmes raised widespread controversy despite the fact that these organisations were only in charge of a small portion of these plans. Most of them were administered by local governments (Longa, 2019).
}

Global Labour Journal, 2021, 12(3), Page 250 
Pacifico, 2020).

As mentioned above, unemployment and poverty reached unprecedented levels by the late 1990s and early 2000s, leading to a period of intense economic, political and social instability that by late 2001 resulted in the resignation of President Fernando de la Rúa (1999-2001) and the appointment of Senator Eduardo Duhalde (2002-2003) as a provisional president. A key initiative during Duhalde's term was the implementation of a massive social assistance programme that merged and expanded existing programmes into the Unemployed Heads of Households Plan (PJJHD, Plan Jefes y Jefas de Hogar Desocupados). It consisted of a small cash transfer to heads of unemployed household with children under the age of eighteen or with disabled children. Recipients were expected to perform some type of community work for local municipalities or social organisations, and to commit to sending their children to school and following the mandatory vaccination schedule. Reaching two million beneficiaries, the programme became the most massive social assistance initiative to date. While the PJJHD sought to appease social conflict by addressing the urgent needs of a growing number of impoverished families, it did not manage to achieve the objective. In a context of acute economic, political and social crisis Néstor Kirchner (2003-2007) was elected president of the country in April 2003. The swift economic recovery and the major political change of the following years would set the scene for major realignments in unemployed workers' movements and in social assistance policy, which were key to situate the emergence of CTEP by the turn of the decade.

\section{Persistent precarious labour, social assistance policies and the transformation of the piquetero movement}

Under Kirchner's lead, economic growth averaged 8.8 per cent per year after 2004 (Felder and Patroni, 2018b), and by mid-2007 unemployment had been reduced to 9.2 per cent from its peak of 21.5 per cent in 2002. Employment creation combined with the rise of wages and non-wage income for workers resulted in a considerable drop in poverty. Nonetheless, by mid-2007, 16.3 per cent of individuals and 23.4 per cent of households were still below the poverty line, and extreme poverty affected 8.2 per cent of individuals and 5.7 per cent of households (INDEC, n.d.[a], n.d.[b]). By 2007, 39.5 per cent of salaried workers were unregistered. Informal workers' average real income was around 50 per cent of that of formal workers and considerably lower than informal workers' income in 1998 (Felder and Patroni, 2018b).

Between 2003 and 2008, the government gradually introduced changes to the existing social assistance programmes, which would ultimately reformulate their very logic. Already in 2003, the Get to Work Plan (Plan Manos a la Obra) was created to give unemployed workers opportunities to acquire equipment to create their own microbusinesses, either individually or with families or communities. In line with the approaches of the 1990s, the programme sought to strengthen the microentrepreneurship ethos in communities as a way to guarantee their subsistence beyond formal labour markets and within the area of economic activity increasingly acknowledged after 2003 as the social economy. The Get to Work Plan was also instrumental in the government's drive to establish connections with piquetero organisations, which promoted these microenterprises to provide some subsistence alternatives for their members. While the government expressed its intention to promote the participation of these organisations in the implementation of social policy, the programme received only 3 per cent of the budget of the Ministry of Social Development in its heyday and was further downgraded after 2005 (Logiudice, 2011).

With the worst of the crisis left behind, by 2004 the government redesigned social assistance once again to focus on programmes facilitating workers' reinsertion into labour markets, including

Global Labour Journal, 2021, 12(3), Page 251 
retraining those who lacked basic labour skills. The underlying assumption at this stage was that economic growth and a concomitant growth in labour demand were the key to reducing unemployment and labour informality (Trujillo and Retamozo, 2019). However, in the following years the government, not without vacillation, started to acknowledge that formal employment creation would not suffice to address precarity. Accordingly, it gradually scaled down the PJJHD and created several programmes to replace it. For example, in 2006 the Training and Employment Insurance programme (Seguro de Capacitación y Empleo) was created under the authority of the Ministry of Labour to temporarily assist unemployed workers - mostly adult men - with the expectation that they would soon join formal labour markets. Other workers who were deemed unemployable due to their unstable job trajectories were offered various programmes based in the Ministry of Social Development. ${ }^{4}$ These first reconfigurations of assistance policies and the division of labour between ministries were early indicators of the government's recognition of the existence of an unemployable population who faced insurmountable obstacles to their reabsorption into waged labour.

Two moments seem to converge during this critical transformation between 2003 and 2008. On the one hand, changing economic conditions translated into the weakening of the piquetero identities that unemployed workers' movements have been so effective in forging and mobilising. Thus, many piquetero organisations redirected their previous demands for jobs to a broader range of concerns connected to the conditions which affected the experience of poverty more generally (Natalucci, 2016; Retamozo and Trujillo, 2018). Redefining themselves as broader social movements, they struggled for access to better public services, urban infrastructure, housing, health care and education. Ensuring access to state resources to provide some improvements to their material life became a fundamental part of their struggles. An important demand in this respect was centred around public support for cooperatives to address the various deficits these communities faced while at the same time creating employment for their members.

On the other hand, the opening of spaces to participate in various spheres of government generated a new line of division within the movement. While some organisations and leaders saw the opportunity to actively engage with the new administration as a way of expanding the political, symbolic and material means to increase their connections to the grassroots, others remain extremely critical both of the orientation of the new government and of collaborating with it (Logiudice, 2017). At the same time, being part of the political alliance in government did not solve all the challenges these organisations confronted in consolidating their own political power on the ground (Gómez and Massetti, 2009). Likewise, their increasing participation in government was not the necessary condition to gain greater power over the administration of resources (Longa, 2019). This would become even more challenging after 2005, when the government moved decisively to downscale assistance programmes delivered in cooperation with social organisations, favouring instead conditional cash transfer policies (Logiudice, 2017). It is in this process of shifting identities and alliances that we locate the main dynamic in the emergence of the CTEP a few years later.

\section{Organising popular economy workers: The creation of CTEP}

It was not until after 2009, during the government of Cristina Fernández de Kirchner (2007-2015),

\footnotetext{
${ }^{4}$ An example of this was the Family Plan for Social Inclusion (PFIS, Plan Familias para la Inclusión Social) created in 2005, which granted a stipend to women with children on the condition that they commit to sending their children to school and comply with standardised health controls.
}

Global Labour Journal, 2021, 12(3), Page 252 
that renewed attention was paid to the universe of precarious and informal workers and, as we will see below, community initiatives in the form of cooperatives re-emerged as key options in social assistance policy. At that point, Fernández de Kirchner's 2007 landslide presidential victory had given way to a series of setbacks. Despite the accelerated economic growth of the previous years, by 2009 unregistered workers still represented 35.8 per cent of salaried workers (Felder and Patroni, 2018b). After the economic downturn of 2008-2009, the pace of formal job creation and real wage growth slowed down, and the income gap between formal and informal workers widened (Morris, 2017). By 2011, up to 45 per cent of all workers in Argentina, both salaried and self-employed, still worked informally (Bertranou, Casanova and Sarabia, 2013: 20). Moreover, and of direct relevance to our argument, unwaged workers - that is, those who continued to make a living by engaging in some type of subsistence economic activity - continued to represent a stubbornly high portion of the working population.

The economic slowdown and persistent labour market fragmentation were compounded by growing political challenges. The government's widespread political support of the previous years gave way to growing levels of opposition, eventually even from the CGT, traditionally a strong ally of Peronist governments. To compensate for the loss of support, in what would constitute a major shift in social policy and programme delivery since 2005 , the government turned its attention to the informal and unemployed sector that had remained marginal to the benefits emerging from rising employment.

Accordingly, in 2009 the government broadened the scope of subsidised employment programmes with the creation of the Social Income with Work-Argentina Works Programme (PRIST-AR, Programa Ingreso Social con Trabajo-Argentina Trabaja). The innovation of this programme was that it implemented assistance through worker cooperatives of up to sixty members, granting them a monthly stipend to carry out public works in poor cities, towns and neighbourhoods. The programme did prompt the growth of the cooperative sector, but under specific conditions. Promoted by the state, cooperatives became the vessel for implementing a social programme that brought together beneficiaries who did not have any particular connection either to other members of their cooperative or to the principles of cooperativism itself (Logiudice, 2017; Hopp, 2018). Nonetheless, the programme offered opportunities for organising around community needs that in many ways proved to be transformative for social organisations. Workers' stipends as members of a cooperative were considerably higher than those in other assistance programmes, and beneficiaries received health insurance and social security benefits as selfemployed workers (Logiudice, 2011). By 2010, 150000 workers organised in 1600 cooperatives had joined the programme (Guimenez and Hopp, 2011), and by 2015 there were 7781 cooperatives organising more than 300000 beneficiaries (Hopp, 2018: 116). Organisations close to the Kirchner administration benefitted most directly from the programme, while more autonomous organisations only managed to secure some participation after a long struggle (Longa, 2019). Division lines also opened between social organisations and the Social Development Ministry, as a growing portion of the budget for the cooperatives was assigned through local governments. These resources that PRIST-AR made available through social organisations and local government officials were instrumental in reshaping the basis of the relative power in the areas where most of the beneficiaries lived and their cooperatives functioned. In parallel, in 2010 the government sanctioned a law enacting the Universal Child Allowance (AUH, Asignación Universal por Hijo), which granted family allowances to all low-income informal and unemployed 
workers. $^{5}$

It was in this context of accommodation but also dissonance with the government that, in 2011, a group of social organisations joined forces to create CTEP as a tool to mobilise the demands emerging from the experience of workers in the PRIST-AR cooperatives (Larsen and Hindi, 2013). These objectives became central to CTEP's founding premise that the process of mobilising workers who have built their livelihoods around precarious and informal occupations needed to bring attention to their work as socially relevant and themselves not as unemployed workers but as workers in the popular economy.

As we mentioned before, CTEP was an outcome of reformulations in the identities and goals of the piquetero movements of the 1990s and early 2000s, which gradually moved from demands for job creation to the notion that the activities they performed within the popular economy constituted work in its own right. CTEP has emphasised the contribution of these activities to the satisfaction of needs and to a whole range of markets in the broader economy, which is why they warranted the protection and resources required to make them viable and sustainable forms of livelihood. A core component of CTEP's call for action in this respect was its understanding that the reality faced by workers in the popular economy was an outcome of changes in contemporary capitalism that have favoured economic concentration and financialisation; this only added to the incessant incorporation of labour-saving technologies that condemn a large segment of workers to chronic unemployment. This stance reflects its fundamental scepticism about addressing unemployment with strategies focused on economic growth. As Esteban Castro, Secretary General of CTEP, explained in 2017:

By the end of 2010 and early 2011, we were a group of organisations fully engaged in political work with popular movements... We began to see how the process of economic concentration in contemporary capitalism and technological change had become obstacles for work creation. We had been aware of this problem before, but at this time we understood we had reached a point of no return (cited in Muñoz, 2019: 490).

This characterisation points to a fundamental area of tension that, with differing intensity, has shaped CTEP's relationship with both the government and the organised labour movement insofar as both continued to peg the resolution of the problem of informality on accelerating economic growth, particularly when combined with the enforcement of norms promoting registered employment (Palomino, 2010; Anigstein, 2019). CTEP's view that demands for job creation were bound to be met with limited success also differentiated it from the goals of the movements of unemployed workers that had emerged in the 1990s.

The demand to be recognised as workers bolstered CTEP's two central strategies: first, the institutionalisation of a social salary as a way to transcend the drawbacks of social assistance programmes, and second, gaining recognition as a labour union - a demand presented to both the state and the organised labour movement. Yet, as the government characterised precarity as a critical but mostly transitory problem, its proposed forms of social intervention were geared towards the eventual incorporation of precarious workers into formal labour markets. The tension between the two appraisals has been central in delineating the relationship between CTEP and the

\footnotetext{
5 The AUH has been a way to extend to informal workers the right to a family allowance, which formal workers have enjoyed since 1957.
} 
government, and the areas of negotiation and accommodation in which they engaged. Part of the explanation for the government's refusal to accept CTEP's key demands was its reluctance to openly abandon the premise so central to the developmentalist vision - that precarity would eventually recede as economic growth progressed.

First, the social salary ran against the government's understanding that social assistance programmes should not become an obstacle for the creation of genuine employment or a disincentive for informal workers to seek employment beyond the options the popular economy afforded them. This fundamental tension in perceptions is most easily gauged in the government's hesitation to fully back the work of the cooperatives through which CTEP sought to bring economic and political organisation to its members (Natalucci, 2012; Longa, 2019).

Second, CTEP's demands that its members be recognised as workers also supported its call to gain status as a union with the right to both engage in collective bargaining and to be protected by a collective agreement (Abal Medina, 2017). This has been challenging on a number of fronts, not least because organising unwaged workers and others who do not have a visible employer is substantially different from the experience of conventional trade unions. But it was also seen by CTEP as an effective tool for unifying such a heterogeneous body of workers in the context of Argentina's history of strong unionisation and working-class identities.

Notwithstanding the strong connections of some of CTEP's leaders and political organisations to Fernández de Kirchner's government, the official response was resounding negative. That position that only changed after the electoral defeat of 2015 and just days before leaving power, when the Ministry of Labour granted CTEP legal recognition. While not equivalent to union certification, its new standing provided the means to gain some collective rights, in particular the possibility of offering its own health care plan to its members (obra social). ${ }^{6}$ The assessment of a then high-ranking official in the Ministry of Labour reveals a delay on the part of the government to fully grasp the efforts of organisations connected to precarious workers to provide some resolution to a large number of unmet basic needs.

They assume, and I have learned to assume, that there exists an economy on the edges [of the country's main economy] that ... in many respects is a fundamental component of the value chain. The main problem is that, to explain it somehow, it is undervalued. For example, the informal garbage collector (cartonero) is fundamentally a key participant ... in the value chain of paper production. Similarly, we can identify several other examples. I said 'I have learned' because I do not think the same way today as I did then. My role in government taught me many things. With some of them I became quite upset, such as with CTEP. But now I have learned to appreciate others, such as cooperatives.... As a labour lawyer, I was suspicious of cooperatives because they are a channel for considerable fraud. But the truth is that the labour cooperatives that grew so much during our government were aimed at something different. They aimed to become new forms of organising the labour process.... We need to provide cooperatives with more formality. They cannot be marginal (Ministry of Labour official, personal interview, February 2020).

This back and forth between the government and CTEP reflects the tensions that unfolded between CTEP's reliance on state resources for sustaining the work in the popular economy, the political participation of some if its leaders in the governing coalition, ${ }^{7}$ and the discrepancies in the

${ }^{6}$ The Health Plan for Popular Economy Workers (OSTEP, Obra Social de Trabajadores de la Economía Popular) was officially sanctioned in December 2016.

${ }^{7}$ The government created new state agencies and appointed CTEP members to lead them. 
characterisation of the nature of precarious labour and CTEP's desire to establish some degree of autonomy for the sector to pursue its political development (CTEP organiser, Buenos Aires, personal interview, August 2020). These tensions would soon be framed in quite different terms with the political changes brought about by the election of Mauricio Macri (2015-2019) and his right-wing alliance.

\section{The "Right Turn": New Challenges and Opportunities for CTEP}

Mauricio Macri's electoral campaign brought together a diversity of slogans ranging from zero poverty to the need to create a more hospitable environment for business, recover the culture of work and leave behind decades of populism and its alleged profligacy and supposedly ill-conceived policies. These ambitious goals were at odds with the succession of misguided policies that followed and resulted in yet another major economic crisis in the country. Except for 2017, there was a sharp decline in economic growth, inflation became an even bigger problem than it had been before 2015, the country was faced once again a major foreign debt crisis, and social and labour market indicators suffered a considerable decline in 2018 and 2019. In this context, Macri lost his bid for re-election in October 2019.

Predictably, amid a long economic slowdown and several periods of acute macroeconomic instability, social and labour market indicators gradually deteriorated. Between the second trimester of 2015 and the second trimester of 2019, unemployment rose from 6.6 per cent to 10.6 per cent of the economically active population. Unregistered employment grew from 33.1 per cent of the active population in the second trimester of 2015 to 35.9 per cent during the third trimester of 2019, and 369000 formal jobs were eliminated in the four years between September 2015 and September 2019 (CETyD, 2019). Equally unsurprising, the purchasing power of salaries and social transfers also deteriorated. Overall, by mid-2019, wages in the private sector had lost approximately 12 per cent of their purchasing power compared to 2015, and wages in the public sector lost more than 30 per cent (Basualdo et al., 2019). Losses were unevenly distributed, affecting lower-income workers the most (Fernández and González, 2019). Social assistance benefits also declined. Thus, between 2015 and September 2019, the purchasing power of the income of cooperative members declined by 16 per cent, and benefits for AUH recipients dropped by 18 per cent (Logiudice, 2020).

As economic, labour market and social indicators were becoming worse, the government gradually gave up on its campaign promises to lead a through transformation of the economy and politics of the country and focused instead on managing economic instability and social conflict, often with meagre results. During the first two years, the government seemed to show some openness towards negotiations with organisations like CTEP. Towards the end of 2017 and after its electoral victory in the mid-term election, the government attempted to intensify its austerity agenda and make progress in the structural reforms associated with it. Its proposals to reform the pension system and deregulate labour markets were expressions of this shift. In December 2017, the government succeeded in obtaining congressional approval to reform pension laws to effectively reduce benefits. Yet this resulted in a major political setback as the reform was passed amid massive protests and ultimately galvanised social dissatisfaction with the government. Under these circumstances, the attempt to pass a law to eliminate labour regulations was postponed. As we will discuss in the next section, in the following two years, mounting social conflict amid the government's virtual loss of control over the economy made it impossible to undermine the power of social organisations in the way it had expected.

Global Labour Journal, 2021, 12(3), Page 256 


\section{Between the restriction of rights and rising social conflict}

As mentioned above, in his electoral campaign, Macri pledged to reach zero poverty and recover the culture of work instead of subsidising unemployed and precarious workers - the approach followed by the Kirchner administration that had elicited so much anger from many of Macri's voters. The tensions between these stated objectives and the political realities of the moment soon became evident. The potentially explosive situations of extreme poverty and the demonstrated capacity of CTEP and other organisations to mobilise around the impact of the government's policies on precarious workers made the cost of reducing social programme spending blatantly clear. Thus, during its first two years, the government kept some channels of communication with CTEP open. Nonetheless, the relationship became increasingly marked by tension, and the organisation ultimately became a major force of opposition against the government. Proposed changes to PRIST-AR provide a good illustration of this. In the government's first months in office, it moved to eliminate the programme, but the initiative met with resistance amid worsening labour and social indicators in the second half of 2016. The government was forced to back down from its original plan, instead introducing only minor changes while the number of cooperatives and individuals receiving assistance grew (Arcidiácono and Bermúdez, 2018). Significantly, CTEP took on key powers as an implementing agency for the programme as the government was willing to disengage itself from the complexity of the everyday management of the programme. This in turn gave CTEP more power and visibility in specific territories.

Struggles around the attempt to dismantle PRIST-AR and the government's need to manage social unrest also provided the right context for CTEP's successful mobilisation to obtain approval for a Social Emergency Law in December 2016 with the support of other sectors of the organised labour movement (Silva Mariños, 2020). The law included the institution of a social salary, created a mechanism for collective negotiations and registration of popular economy workers, and recognised the right of these workers to access basic services and to enjoy the protection of some labour rights. The sanction of the law was a victory for CTEP because it incorporated, albeit with limitations, some of its key demands, advancing the recognition of popular economy workers as workers.

The social salary would allow popular economy workers to receive an income established as a proportion of the legal minimum wage in exchange for the economic activities they were already performing. For CTEP the abandoning of the idea of an assistance plan in favour of a law regulating a salary that compensated workers for their work within the popular economy was perceived as a fundamental step in securing not only greater stability but also more autonomy for their members. The Council for the Popular Economy and the Supplementary Social Salary (Consejo de la Economía Popular y del Salario Social Complementario) was created to make decisions about the allocation of public funding to popular economy workers with the participation of the Ministry of Social Development, the Ministry of Labour and the Ministry of the Economy as well as representatives of the popular economy organisations. The law also established the creation of a Registry of Popular Economy Workers (RENATEP, Registro de Trabajadores de la Economía Popular) to collect information about the recipients of social assistance cash transfer programmes, which were all to be gradually replaced by the Supplementary Social Salary. ${ }^{8}$

CTEP continued mobilising to demand the effective implementation of the Social Emergency

\footnotetext{
${ }^{8}$ The RENATEP was not implemented during the Macri government, and was only put into practice in July 2020 by the Alberto Fernández (2019-2023) government amid the crisis produced by the COVID-19 pandemic. In its first month of existence, almost 500000 popular economy workers registered (Vales, 2020).
}

Global Labour Journal, 2021, 12(3), Page 257 
Law and, with other labour organisations, to confront the impacts of the critical economic situation on workers. Because of the government's attempt to resume its austerity agenda, social mobilisation at this stage could only fuel further confrontation. In this context, in 2018 the government sought to repurpose social assistance as a means of curtailing the power of precarious workers' organisations, particularly that of CTEP. On the argument that cooperatives had failed to become sustainable and competitive, the PRIST-AR and other smaller programmes were replaced by the We Make the Future (Hacemos Futuro) programme (Hudson, 2020). The new programme eliminated work conditionality, requiring recipients to attend training activities instead. This shift towards training (Arcidiácono and Bermúdez, 2018) did not only seek to put an end to cooperative work but also to weaken the links between individual recipients of assistance and popular economy organisations, which were now displaced from their role in programme implementation. In response, social organisations tried to retain their connections with their communities by fostering a number of alternative programmes, especially training and popular education centres, and by continuing to work collectively to solve local problems (Pacifico, 2020).

Social policy under Macri did not fully follow the pattern delineated in his electoral campaign. Of special interest here is the fact that the government did not eliminate social assistance programmes, as hoped by many of its supporters. The ideological premises about the culture of work that informed the attempt to eliminate assistance was mediated by other considerations, and to some extent left aside, as the priorities associated with the economic crisis and changing balance of forces were setting new limits to the actions of the government. ${ }^{9}$ The alliances through which this balance of forces evolved are discussed in the following pages.

\section{Seeking recognition from other workers: CTEP's relation to CGT}

Despite its caveats, the passing of the Social Emergency Law was a major political achievement for CTEP and demonstrated its ability not only to mobilise its grassroots, but also to develop alliances with other key labour and political forces, among them CGT, CTA, the Catholic Church and several political parties. In many respects, CTEP's ability to bring these disparate forces together secured its legitimatisation as an actor within the organised labour movement.

The efforts to find common ground among working-class organisations prompted significant changes within them. CTEP actively participated in other unions' actions around dismissals and working conditions (teaching unions, government workers, etc.). It also took part in CGT and CTA strikes and demonstrations as a part of its strategy to build alliances and incorporate its own demands into organised workers' agendas (Hindi, 2020). ${ }^{10}$ In a similar fashion, in 2016 CGT created new Secretariats for the Popular Economy in several of its regional offices, placing them under the administrative control of the Brickmakers' Union (UOLRA, Unión Obrera Ladrillera de la República Argentina), an organisation politically linked to CTEP and to Movimiento Evita.

At the same time, CTEP asserted in no ambiguous terms its desire to become part of CGT. This is a decision in need of accounting given CGT's less than exemplary history in terms of addressing the changes in labour markets, especially rising precarity, and the existence of an

\footnotetext{
${ }^{9}$ Indeed, between 2015 and 2019 funding for social assistance programmes increased, and the number of recipients of social assistance continued to grow. By 2019, there were 298620 recipients of the Supplementary Social Salary and 236620 beneficiaries of the We Make the Future programme, the latter only slightly lower than the 245536 beneficiaries of the Argentina Works programme in 2015 (Ministerio de Economía, n.d.).
}

${ }^{10}$ For a detailed account of these actions during the period 2016-2019 see Silva Mariños (2020). 
alternative confederation - CTA - with some concrete experience in organising informal workers. Three factors seem to us of particular relevance. The first is the particular moment of union renewal as rising formal employment in the first decade of the new century had allowed CGT to accumulate important power (Marticorena, 2015). At the same time, CTA was an organisation facing growing internal divisions, and questioning its own decision to split the labour movement in Argentina in the 1990s (CTA member, personal interview, 2016). Second, there were strong political affinities between CTEP and CGT, particularly their connection to Peronism and the imaginary of workingclass unity so central in the historical configuration of working-class identity in Argentina. In other words, CGT embodied a tradition of union representation that was recognised as legitimate. Finally, there was probably no more certain path for informal workers to gaining recognition as workers than being able to join CGT (Natalucci and Morris, 2019). Nonetheless, the alliance cemented around the struggles for the Social Emergency Law was a source of considerable tension within CGT. This tension reflected the trepidations of CGT's leadership about the incorporations of CTEP, a quite large umbrella organisation bringing a substantial membership with divergent priorities, whose incorporation into CGT had the potential to alter the internal balance of forces (Patroni, 2018).

In 2018 the sectors within CGT that had been quite receptive to incorporating CTEP particularly those responding to the leadership of Juan Carlos Schmidt, one of three co-presidents of the organisation at that time - were displaced from power. Schmidt's advocacy to recognise CTEP as part of the labour movement remains a moment of contention within the CGT worth reflecting upon. In his own words, during a demonstration demanding the passing of a social emergency law in 2016:

\begin{abstract}
We are facing a momentous transformation, the forging of a common tool between unions and social and popular movements in the country. Here, to my right, we find national unions representing men and women protected under collective agreements and enjoying all the protection of labour laws. To my left are millions of Argentines who get up every day without knowing how they will feed their families. It is a very heterogeneous universe composed of ... those who must try to secure a living and a place in a system that denies them any kind of assistance (cited by Muñoz, 2019: 501).
\end{abstract}

By the time of Schmidt's departure, CGT was going through intense internal debate between a leadership favourable to engaging in dialogue with the government and sectors more willing to converge with other popular and labour organisations in a more open confrontation with it (Silva Mariños, 2020). Amid these tensions, the incorporation of CTEP represented a source of potential instability the leadership was not willing to take.

Beyond the alliance between CTEP and the other two major labour confederations in Argentina, the struggle around the Social Emergency Law helped a number of social movements find a way to overcome their divisions and demobilisation. Importantly, CTEP was able to bring some of these organisations under its umbrella, as was the case with Neighbourhoods Standing Up (BdP, Barrios de Pie) and Classist and Combative Current (CCC, Corriente Clasista y Combativa). Finally, while CTEP might still lack recognition as a union by CGT, the latter nonetheless accepted its incorporation into the country's Salary Council (Consejo del Salario), in which representatives of the federal state, provincial governments, employers and unions meet periodically to deliberate and agree on criteria about various labour relations issues, among them decisions about the legal minimum wage.

By 2019, mobilisations became increasingly influenced by the context of the incoming presidential election in which a broad number of sectoral demands became combined with calls by

Global Labour Journal, 2021, 12(3), Page 259 
several union leaders to defeat Macri's bid for re-election (Silva Mariños, 2020). The change of government in December 2019 created widespread expectations of recovery from the losses suffered during the previous four years among the various sections of the labour movement. Soon after, the COVID-19 pandemic made the relevance of the work of popular economy workers, especially of their care and reproductive work, evident, while at the same time it greatly restricted their livelihoods. Very much as it has happened elsewhere, there appears to be a more propitious moment to invite reflection about the value of the essential work of those who for many appeared marginal in their contribution to the economy and society. Whether this moment can be sustained to support further change remains to be seen.

\section{Conclusions}

For many precarious workers around the world, the most fundamental demand is that of being recognised as workers and their productive activities seen not only as legitimate but also as relevant to the economy as a whole (Budlender, 2013; Agarwala, 2014). The case of CTEP calls attention to the challenges of gaining such recognition, and to the many spheres in which recognition as workers has been fought for. With its own tensions and dilemmas, the overarching goal has been to broaden options related to the reproduction needs of individuals and communities beyond the narrow and unpredictable boundaries of social policy.

As our work shows, assistance policy has been a key arena of negotiation and contention between precarious workers and the state. The way in which such assistance is distributed can have impacts that transcend the individual, affecting communities more broadly and, centrally to our argument, the organisations that strive to represent those workers, their goals and their forms of collective action. The nature of assistance programmes, their scope and the manner of their implementation have been important factors in the struggles of workers in the popular economy, not least because these workers have tried to frame their demands in ways that seek to transcend the realm of social policy. Instead, they have demanded recognition as workers who deserve rights under the law.

In placing these demands, CTEP's actions have often been disruptive. As its workers lack a site of employment, they have sought, as Murray Li (2017: 125) puts it, to "exert some leverage simply through their presence" in the public space. Understanding this presence has been the purpose of our work: how it is manifested and conditioned by the structural conditions of precarity and the relations with the state and other actors, and the balances of forces between them. CTEP has been able to make sense of challenging structural transformations in the world of work in novel ways that have given political meaning and sustainability to the travails of precarious workers. The specific ways in which CTEP has connected the multiple dimensions and spheres through which precarious workers strive to gain recognition as workers, including their connections with the state through social assistance and with the organised labour movement, have been markedly innovative in the country and the region. Fundamentally, what is still to be seen is whether the innovations CTEP pursues will suffice to guarantee the social reproduction of informal workers in conditions of dignity and fairness, especially in the context of economic and political uncertainty brought about by the COVID-19 pandemic.

Our work has touched upon a number of issues that open avenues for future research. One of them is whether organisations like CTEP can play a role in reinvigorating working-class struggles and unions more broadly. As we have shown, while CTEP has made important gains in forging alliances within the labour movement, struggles around definitions and redefinitions of work will

Global Labour Journal, 2021, 12(3), Page 260 
expectedly demand considerably more efforts on the part of the different segments of a highly heterogeneous labour movement. Studies of labour movements have much to contribute in elucidating the nature and expression of the tensions between these sectors, including the conventional labour movement's neglect of the predicament of precarious workers combined with their concerns about opening the door for legitimising labour precarity and informality. While the heterogeneity of the labour movement is closely connected with the structural fragmentation of labour markets, this fragmentation has been increasingly mediated by the state through social assistance policy. State intervention in this sphere raises important questions about its implications for the constitution of working-class identities and the likelihood of alliances between formal workers and a growing group of precarious assisted workers.

While we have focused our discussion on the relationship between a particular organisation representing precarious workers and the state, we are aware of the diverse intra- and interorganisational processes pivotal in understanding the definition of precarious workers' strategies and struggles. This points to the need for further research into the connections, alliances and conflicts among the organisations and groups representing what is by definition an extremely diverse segment of the working class.

Finally, another crucial question emerging from our discussion above is the extent to which forms of income guaranteed by the state - as is the case of the social salary discussed here - are effective tools to address the structural conditions underlying poverty and inequality. This resonates with the contentious historical trajectories of wage subsidies and the wellbeing of working people and to the very basic problem of taxation and the contested ability of the state to count on fiscal resources for redistribution. The possibilities ahead, as we hope our discussion indicates, must be understood as open-ended processes, in which the relations between actors and policy outcomes are not pre-determined and thus may evolve in different directions, including that of greater fairness.

\section{References}

Abal Medina, P. (2016) Los trabajadores y sus organizaciones durante los gobiernos kirchneristas. Nueva Sociedad, 264 (July-August): 72-86.

Abal Medina, P. (2017) Los movimientos obreros organizados de Argentina (2003-2016). In ¿Existe la clase obrera? edited by P. Abal Medina, A. Natalucci and F. Rosso. Buenos Aires: Capital Intelectual.

Agarwala, R. (2014) Informal Workers' Struggles in Eight Countries. Brown Journal of World Affairs, 20(2): $251-264$

Álvarez Leguizamón, S. (2006) La invención del desarrollo social en la Argentina: historia de "opciones preferenciales por los pobres". In Problemas de politica social en la Argentina contemporánea, edited by Luciano Andrenacci. Los Polvorines: Editorial Prometeo- Universidad Nacional de General Sarmiento.

Andrenacci, L. (2002) Algunas reflexiones en torno a la cuestión social y la asistencialización de la intervención social del estado en la Argentina contemporánea. In Cuestión social y política social en el Gran Buenos Aires, edited by Luciano Andrenacci. La Plata: Ediciones Al Margen- Universidad Nacional de General Sarmiento.

Anigstein, C. (2019) La irrupción del sindicalismo neodesarrollista: la CGT y los gobiernos kirchneristas (2002-2012). Estudios del Trabajo. Revista de la Asociación Argentina de Especialistas en Estudios del Trabajo (ASET), 57: 1-26. 
Arcidiácono, P. and Á. Bermúdez (2018) ¿Cooperativismo como oportunidad perdida? Problemas estructurales y coyunturales del cooperativismo bajo programas. Ciudadanías. Revista de Politicas Sociales Urbanas, (2): 83-111.

Basualdo, E., P. Manzanelli, M.J. Castells and M. Barrera (2019) Informe de coyuntura No 32. Buenos Aires: Centro de Investigación y Formación de la República Argentina (CIFRA). http:/ / www.centrocifra.org.ar/docs/32.pdf (accessed 30 June 2020).

Benclowicz, J.D. (2015). Movimiento de trabajadores desocupados en la Argentina y cultura obrera: una perspectiva histórica. Revista Esboços, 22(33): 128-147.

Bertranou, F., L. Casanova and M. Sarabia (2013) How, Why and in What Sectors Employment Informality Decreased in Argentina from 2003 to 2012. Paper presented at the Third Regulating for Decent Work Conference, "Regulating for Equitable and Job-Rich Growth", Geneva, 3-5 July 2013.

Bonner, C. and D. Spooner (2011) Organizing in the Informal Economy: A Challenge for Trade Unions. Internationale Politik und Gesellschaft, 2: 87-105.

Brown, B. (2017). Sistema de protección social y Programas de Transferencias Monetarias Condicionadas. El "paradigma de la activación" en Argentina 2003-2013 (Parte 2). Documento de Trabajo Número, 100. Buesos Aires: CIEPP.

Budlender D. (2013) Informal Workers and Collective Bargaining: Five Case Studies. WIEGO Organizing Brief 9. Manchester: WIEGO. https://www.wiego.org/sites/default/files/publications/files/ Budlender-Informal-Workers-Collective-Bargaining-WIEGO-OB9.pdf (accessed 3 February 2019).

Bruno, D.P., R. Coelho, and M.M. Palumbo (2017) Innovación organizacional e institucionalización conflictiva de las organizaciones de la economía popular. Argumentos, 19 (October): 90-119.

Capacitación y Estudios sobre Trabajo y Desarrollo: Seguimiento de la Situación Laboral (CETyD) (2019) Update \#17, December. http://www.cetyd.unsam.edu.ar/documentos/situacion-laboral/ seguimiento completo.pdf (accessed 20 June 2020).

Chen, M.A. (2012) The Informal Economy: Definitions, Theories and Policies. WIEGO Working Paper No. 1. Manchester: WIEGO. https://www.wiego.org/publications/informal-economy-definitions-theoriesand-policies (accessed 15 March 2021).

Coraggio, J. (2020) Economía social y economía popular: conceptos básicos. Buenos Aires: Instituto Nacional de Asociativismo y Economía Social. https://www.argentina.gob.ar/sites/default/ files/coraggio.pdf (accessed 1 March 2021)

Cross, C. and J. Montes Cató (2002) Crisis de representación e identidades colectivas en los sectores populares. Acerca de las experiencias de las organizaciones piqueteras. In La atmósfera incandescente. Escritos politicos sobre Argentina movilizada. edited by O. Battistini. Buenos Aires: Trabajo y Sociedad.

Danani, C. and S. Hintze (2010) Reformas y contrarreformas de la protección social: la Seguridad Social en la Argentina en la primera década del siglo. Revista Reflexión Politica, 12(24): 18-29.

Dinerstein, A.C. (2014) The Dream of Dignified Work: On Good and Bad Utopias. Development and Change, 45(5): 1037-1058.

Dinerstein, A.C. and F. Pitts (2018) From Post-Work to Post Capitalism? Discussing the Basic Income and Struggles for Alternative Forms of Social Reproduction. Journal of Labor and Society, 21(4): 471-491.

Felder, R. and V. Patroni (2011) Austerity and its Aftermath: Neoliberalism and Labour in Argentina. Journal of Socialist Studies, 7(1): 259-281.

Felder, R. and V. Patroni (2018a) Organizing the unorganisable: The Case of Popular Economy Workers in Argentina. Journal of Labour and Society, 21(2): 121-136.

Felder, R. and V. Patroni (2018b) Precarious Work in Recession and Growth: A New Structural Feature of Labor Markets in Argentina? Radical Review of Political Economics, 50(1): 44-65. 
Fernández, A. and M. González (2019) Informe sobre situación del mercado de trabajo, 6. Buenos Aires: Centro de Investigación y Formación de la República Argentina (CIFRA). http://www.centrocifra.org.ar/ docs /CIFRA $\% 20$ Informe $\% 20$ mercado $\% 20$ de $\% 20$ trabajo $\% 20$ Nro6.pdf (accessed 20 June 2020).

Fernández Álvarez, M.I. (2019) “Having a Name of One’s Own, Being a Part of History”: Temporalities of Precarity and Political Subjectivities of Popular Economy Workers in Argentina. Dialectical Anthropology, 43(1): 61-76.

Fernández Álvarez, M.I. (2020). Building from Heterogeneity: The Decomposition and Recomposition of the Working Class Viewed from the "Popular Economy" in Argentina. Dialectical Anthropology, 44(1): 57-68.

Fernández-Álvarez, M.I., and M. Perelman (2020) Perspectivas antropológicas sobre las formas de (ganarse la) vida. Cuadernos de antropología social, 51: 7-21.

Forni, P., T. Nougués M. Zapico (2020) La Economía Popular como identidad colectiva. El camino a la unidad de los movimientos y organizaciones populares en la Argentina (2011-2019). Colección, 31(2): 73108.

Freytes Frey, A. and C. Cross (2005) Políticas sociales y tradiciones ideológicas en la constitución de los movimientos de trabajadores desocupados. Paper presented at the $7 \mathrm{mo}$. Congreso Nacional de Estudios del Trabajo. Asociación Argentina de Especialistas en Estudios del Trabajo. Buenos Aires, August 2005. https://aset.org.ar/congresos/7/12021.pdf (accessed 20 February 2021).

Garay, C. (2007) Social Policy and Collective Action: Unemployed Workers, Community Associations, and Protest in Argentina. Politics \& Society, 35(2): 301-328.

Gómez, M.F. and A. Massetti (2009) Los movimientos sociales dicen: conversaciones con dirigentes piqueteros. Buenos Aires: Nueva Trilce.

Grabois, J. (2014) Introducción. In Organización y economía popular: nuestra realidad (Vol. 1), edited by J. Grabois and E. Pérsico. Buenos Aires: CTEP - Asociación Civil de los Trabajadores de la Economía Popular.

Grassi, E. (1997) Políticas sociales, necesidades y la cuestión del trabajo como capacidad creadora del sujeto humano. In Empleo y Globalización: La nueva cuestión social en la Argentina, edited by E. Villanueva. Bernal: Universidad Nacional de Quilmes.

Grassi, E. (2003) El asistencialismo en el Estado Neoliberal. La experiencia argentina en la década del '90. Revista e-l@tina. Revista electrónica de estudios latinoamericanos, 1(4): 27-48.

Guimenez, S. and M. Hopp (2011) Programa Ingreso Social con Trabajo "Argentina Trabaja": una mirada reflexiva desde el corazón de su implementación. Paper presented at the 4th Encuentro Internacional Trabajo Social de la Universidad de Buenos Aires, Buenos Aires, 12-13 May.

Hindi, G. (2020) Apuntes antropológicos sobre debates actuales: clases trabajadoras y economía popular en la Argentina. Iluminuras, 21(52): 239-261.

Hopp, M. (2018) De la Promoción del Trabajo Cooperativo al Salario Social Complementario. Transformaciones en la Transferencia de Ingresos por Trabajo en la Argentina. Ciudadanias, 2 (September): 113-142.

Hudson, J.P. (2020) La representación de los trabajadores informales: el Triunvirato de San Cayetano. Temas y Debates, 39: 35-58.

Instituto Nacional de Estadística y Censos (INDEC) (n.d.(a)) Porcentaje de bogares y personas bajo las líneas de pobreza e indigencia en los aglomerados urbanos y regiones estadísticas desde el primer semestre 2003 en adelante. https://www.indec.gob.ar/ftp/cuadros/sociedad/sh pobrezaeindigencia continua.xls (accessed 10 May 2020).

Instituto Nacional de Estadística y Censos (INDEC) (n.d. (b)). Evolución trimestral de las tasas de desocupación y subocupación en el total de los aglomerados urbanos. Primer trimestre 2003 en adelante. https://www.indec.gob. ar/ftp/cuadros/menusuperior/archivo/sh eph continuasemestral.xls (accessed 10 May 2020). 
Katz, C. (2001). Vagabound Capitalism and the Necessity of Social Reproduction. Antipode, 33(4): 709-728.

Larsen, M. and G. Hindi (2013) Nuevos escenarios de organización de los trabajadores, a partir de la implementación del programa Argentina Trabaja: caso CTEP. VII Jornadas Santiago Wallace de Investigación en Antropología Social. Sección de Antropología Social. Instituto de Ciencias Antropológicas. Facultad de Filosofía y Letras, UBA, Buenos Aires

Lazar, S. and A. Sánchez (2019) Understanding Labour Politics in an Age of Precarity. Dialectical Anthropology, 43(1): 3-14.

Levitsky, S. (2003) Transforming Labor-based Parties in Latin America: Argentine Peronism in Comparative Perspective. New York: Cambridge University Press.

Logiudice, A. (2011) Pobreza y neoliberalismo. La asistencia social en la Argentina reciente. Entramados y perspectivas, 1(1): 61-90. https??publicaciones.sociales.uba.ar/index.php/entramadosyperspectivas/issue /view/13/showToc (accessed 20 January 2020).

Logiudice, A. (2017) La asistencia social actual: entre la aseguración y la activación de los trabajadores. In La trama de las politicas sociales: estado, saberes y territorio, edited by P. Arcidiácono and C. Zibecchi. Buenos Aires: Editorial Biblos.

Logiudice, A. (2017) Continuidades y Rupturas de la Política Asistencial en la Argentina de la Posconvertibilidad (2002-2012). Unpublished doctoral dissertation, University of Buenos Aires.

Logiudice, A. (2020) Tensiones y articulaciones entre los programas asistenciales de empleo y las políticas de transferencias monetarias condicionadas de empleo durante la última década (2009-2019). Ciudadanias. Revista de Políticas Sociales Urbanas, 6: 1-33. http://revistas.untref.edu.ar/index.php/ ciudadanias/issue/view/40 (accessed 18 February 2021).

Longa, F. (2019) Historia del Movimiento Evita: La organización social que entró al Estado sin abandonar la calle. Buenos Aires: Siglo XXI Editores.

Lo Vuolo, R., A. Barbeito, L. Pautassi and C. Rodríguez (1999) La pobreza... de la política contra la pobreza. Madrid: Miño y Dávila Editores.

Lucita, E. (2001) Cortando rutas, abriendo nuevos senderos. Desocupados, ocupados, piqueteros, viejas y nuevas formas de lucha. Buenos Aires, Cuadernos del Sur, 32: 79-93.

Marticorena, C. (2015) "Revitalización" sindical y negociación colectiva en Argentina (2003-2011). Perfiles latinoamericanos, 23(46): 173-195.

Massetti, A. (2004) Piqueteros: Protesta social e identidad colectiva. Buenos Aires: Editorial de las Ciencias.

Ministerio de Economía (n.d.) Cuentas de Inversión. Buenos Aires: Ministerio de Economía. https://www.argentina.gob.ar/economia/sechacienda/cgn/cuentainversion (accessed 10 May 2020).

Morris, M.B. (2017) La revitalización sindical en Argentina (2003-2015): dimensiones e indicadores para su conceptualización. Población \& Sociedad, 24(2): 193-226.

Muñoz, M.A. (2019) Voluntades populares, voluntades laborales. El caso de la Confederación de Trabajadores de la Economía Popular. Trabajo y Sociedad, 32: 479-510.

Murillo, S. (2008) Colonizar el dolor. La interpelación ideológica del Banco Mundial en América Latina. El caso argentino desde Blumberg a Cromañon. Buenos Aires: Consejo Latinoamericano de Ciencias Sociales [CLACSO].

Murray Li, T. (2017) After Development: Surplus Population and the Politics of Entitlement. Development and Change, 48(6): 1247-1261.

Natalucci, A.L. (2012) Políticas sociales y disputas territoriales. El caso del Programa Argentina Trabaja. Revista de Políticas Públicas, 2(3): 126-147.

Natalucci, A.L. (2016) Del piquete a la economía popular. Revista Anfibia, Universidad Nacional de San Martin. https://www.revistaanfibia.com/del-piquete-a-la-economia-popular (accessed 9 August 2020). 
Natalucci, A. and B.M. Morris (2019) ¿Superando la fragmentación? Un análisis de las estrategias de articulación entre la CGT y la CTEP (2009-2017). Astrolabio, 23: 169-197.

Pacifico, F. (2017) Entre lo productivo y lo reproductivo. Un análisis etnográfico del trabajo de mujeres en cooperativas y programas sociales. Fazendo Género, 11: 1-13.

Pacifico, F. (2020) Del Argentina Trabaja al Hacemos Futuro. Apuntes etnográficos para pensar la transformación de los programas sociales desde la experiencia de organizaciones de la economía popular (2016-2018). Revista Estado y Politicas Públicas, 8(15): 165-188.

Palomino, H. (2010). La instalación de un nuevo régimen de empleo en Argentina. In La nueva dinámica de las relaciones laborales en la Argentina, edited by H. Palomino et. al. Buenos Aires: Jorge Baudino Ediciones.

Patroni, V. (2018) Uncertain Transitions: Labor and the Politics of Reform in Argentina. In Labor Politics in Latin America: Democracy and Worker Organization in the Neoliberal Era, edited by P.W. Posner, V. Patroni and J.F. Mayer. Gainesville, FL: University Press of Florida.

Pautassi, L., P. Arciadiácono and M. Straschnoy (2013) Asignación Universal por Hijo para la protección social de la Argentina. Entre la satisfacción de necesidades y el reconocimiento de derechos. Serie Políticas Sociales 184. Chile: Comisión Económica para América Latina y el Caribe [Cepal]-UNICEF.

Pérsico, E. and J. Grabois (2014) Organización y economía popular: Nuestra realidad (Vol. 1). Buenos Aires: CTEP - Asociación Civil de los Trabajadores de la Economía Popular.

Retamozo, M. and L. Trujillo (2018) Cambios estructurales y prácticas de movilización política en Argentina. Dos ciclos políticos en perspectiva (1989-2002 y 2003-2015). Papel político, 23(2). http://www.memoria.fahce.unlp.edu.ar/art revistas/pr.9714/pr.9714.pdf (accessed 12 April 2020).

Rosaldo, M. (2016) Revolution in the Garbage Dump: The Political and Economic Foundations of the Colombian Recycler Movement, 1986-2011. Social Problems, 63(3): 351-372.

Rossi, F. (2017) Más allá del clientelismo: el movimiento piquetero y el Estado en Argentina. Movimientos Sociales en América Latina: Perspectivas, Tendencias y Casos, edited by P. Almeida and A Cordero Ulate. Buenos Aires: CLACSO.

Silva Mariños, L. (2020) Trabajadores de la economía popular frente al gobierno de la alianza Cambiemos. Demandas, actores y unidad de acción en el marco de la protesta social. Observatorio Latinoamericano y Caribeño, 4(1): 141-159.

Sojo, A. (2007) La trayectoria del vínculo entre políticas selectivas contra la pobreza y políticas sectoriales. Revista de la Cepal, 91: 111-131.

Soldano, D. and L. Andrenacci (2006) Aproximación a las teorías de la política social a partir del caso argentino. In Problemas de política social en la Argentina contemporánea, edited by L. Andrenacci. Buenos Aires: UNGS-Editorial Prometeo.

Standing, G. (2011) The Precariat: The New Dangerous Class. New York: Bloomsbury Academic.

Svampa, M. (2008) Cambio de época. Movimientos sociales y poder político. Buenos Aires: Siglo XXI.

Svampa, M. and S. Pereyra (2003) Entre la ruta y el barrio: la experiencia de las organizaciones piqueteras (1a. ed.). Buenos Aires: Editorial Biblos.

Trujillo, L. and M. Retamozo (2019) Políticas contra la pobreza en Argentina (2002-2015). Alcances, limitaciones y desafíos. Revista Reflexiones, 98(1): 89-110.

Vales, L. (2020) Quiénes son y qué hacen las 500 mil personas que ya se anotaron como trabajadores de la "Economía Popular". Página 12, Buenos Aires, August 21.

Vilas, C.M. (1997) De ambulancias, bomberos y policías: La política social del neoliberalismo. Desarrollo Económico, 36(144): 931-952. 


\section{BIOGRAPHICAL NOTES}

MAISA BASCUAS is a popular feminism activist. She holds a degree in Political Science and teaches at the University of Buenos Aires, the National University of General Sarmiento and the Latin American Program of Distance Education in Social Science (PLED). She is a researcher affiliated with the Institute for the Study of Latin America and the Caribbean of the University of Buenos Aires, the Open Memory Archive (Argentina) and the Tricontinental Institute for Social Research. She has published on the state, public policies, Latin American feminism and feminist popular economies. [Email: maisabas@gmail.com]

RUTH FELDER is an assistant teaching professor in the Political Science Program, Faculty of Social Science and Humanities at Ontario Tech University. She is a research fellow of the Institute for the Study of Latin American and the Caribbean of the University of Buenos Aires. Her research focuses on the political economy of development with a focus on Argentina and with attention to class relations underlying the role of the state and policies. [Email: ruth.felder@ontariotechu.ca; corresponding author]

ANA LOGIUDiCE teaches at the Social Science and Psychology Faculty at the University of Buenos Aires and is a researcher affiliated with the Institute for the Study of Latin America and the Caribbean of the same university. Her work focuses on social assistance policies in Argentina since the 1990s, particularly in relation to changing forms of government intervention, the configuration of labour markets and the strategies of working-class organisations and social movements in the country. [Email: analogiudice@gmail.com]

ViVIANA PATRONi is an associate professor in the Department of Social Science at York University. She is a research fellow the Global Labour Research Centre (GLRC) and the Centre for Research on Latin America and the Caribbean (CERLAC), both at York University. Her research focuses on the political economy of Latin America, the transformation of the world of work in this region since the 1980s, the centrality of labour struggles in shaping patterns of development and the transformation of labour markets in Argentina since the 1990s. [Email: vpatroni@yorku.ca; corresponding author] 